
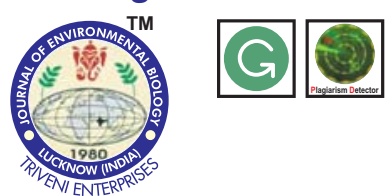

\title{
Evaluation of biocontrol potential of some fungal decomposers of Sesbania aculeata L. green manure against some soil-borne plant pathogens
}

\section{Authors Info \\ Ravindra Kumar ${ }^{1.4 *}$, Asha Sinha ${ }^{1}$ Seweta Srivastava ${ }^{2}$ and Gaurav Mahajan ${ }^{3}$ \\ 'Department of Mycology and Plant Pathology, Institute of Agricultural Sciences, Banaras Hindu University, Varanasi-221 005, India \\ ${ }^{2}$ U.P. Council of Agricultural Research, Lucknow-226 010, India \\ ${ }^{3}$ Department of Agronomy, JNKVV, College of Agriculture, Rewa-486 001, India \\ ${ }^{4}$ ICAR - Indian Agricultural Research Institute, Regional Station, Karnal-132 001, India \\ ${ }^{*}$ Corresponding Author Email : ravindrakumarbhu@gmail.com}

\section{Key words}

Biological control, Fungal decomposers, Green manure, Soil borne phytopathogens

Publication Info

Paper received : 03.10 .2015

Revised received : 18.01.2016 Re-revised received : 30.04 .2016 Accepted :09.06.2016
Abstract

Aim : Soil borne phytopathogens are one of the major concern of today's agricultural system. In the present study, dominant fungal decomposers were selected and their potential as biological control agents was evaluated against some soil borne plant pathogens.

Methodology : Effect of green manure amendment on the sclerotia viability of three soil-borne plant pathogens viz., Sclerotium rolfsii, Rhizoctonia solani and Sclerotinia sclerotiorum, effect of fungal decomposers on soil-borne phytopathogens in dual culture, effect of volatile and non-volatile metabolites of dominant fungal decomposers on the radial growth and sclerotia production of test pathogens were evaluated.

Results : Green manure amendment resulted in reduced in sclerotia of $S$. rolfsii, $R$. solani and $S$. sclerotiorum by 40,36 and $36.50 \%$, respectively. In dual culture, the maximum growth inhibition of $S$. rolfsii, $R$. solani and S. sclerotiorum with Trichoderma harzianum were $49.95,47.62$ and $57.83 \%$, respectively. The maximum inhibition of $S$. rolfsii and $S$. sclerotiorum caused by the volatile metabolites produced by Trichoderma harzianum were 56.64 and $43.95 \%$, whereas the maximum inhibition of $R$. solani was caused by volatile metabolites of Penicillium citrinum (44.96\%). The maximum inhibition of $S$. rolfsii, $R$. solani and S. sclerotiorum through non-volatile metabolites of Trichoderma harzianum were 51.04, 57.30 and $49.10 \%$, respectively. The maximum reduction in sclerotia of $S$. rolfsii, $R$. solani and $S$. sclerotiorum with Trichoderma harzianum were $86.44,88.54$ and $88.20 \%$ respectively, under dual culture after 21 days of incubation. The maximum reduction in sclerotia of $S$. rolfsii, $R$. solani and $S$. sclerotiorum with Trichoderma harzianum were $95.42,93.60$ and $91.32 \%$, respectively, under the effect of volatile metabolites after 21 days of incubation. The maximum reduction in sclerotia of S. rolfsii, $R$. solani and S. sclerotiorum with Trichoderma harzianum were $87.46,79.74$ and $85.10 \%$ respectively, under the effect of non-volatile metabolites after 21 days of incubation.

Interpretation : All eight fungal decomposers effectively contribute in controlling the soil borne phytopathogens. Overall T. harzianum, Aspergillus niger and Penicillium citrinum proved as potential bio-control agents against all soil borne plant pathogens viz., S. rolfsii, $R$. solani and $S$. sclerotiorum.

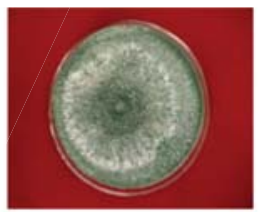

(Potential green manure decomposer)

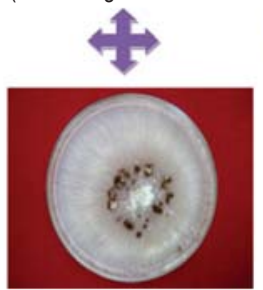

III

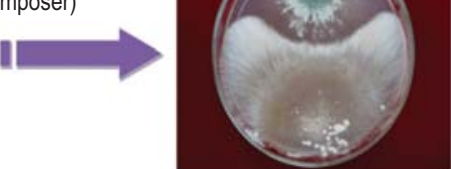

(Management of soil borne phytopathogens by green manure decomposer) 


\section{Introduction}

Soil-borne pathogens, viz., Sclerotium rolfsii, Rhizoctonia solani, Sclerotinia sclerotiorum, Pythium spp. and Fusarium spp. are the most destructive pathogens of wide range of commercially important crops around the world. The extent of damage can be judged from the fact that under favourable agro-climatic conditions, the losses caused by these pathogens may reach up to $100 \%$ (Kapoor, 2008).

The management of soil-borne pathogens is difficult as compared to foliar phytopathogens. The ability of resting structures of some of these soil borne pathogens i.e., sclerotia in case of Rhizoctonia solani, Sclerotium rolfsii and Sclerotinia sclerotiorum withstand adverse conditions and their wide host range makes them highly successful pathogens. Management of soil-borne pathogens with fungicides has been attempted for long time. However, it is difficult to manage these diseases economically with fungicides alone because of their soil-borne nature and wide host range.

The control of soil-borne plant pathogens causing severe diseases in various crops of economic importance presents a great challenge to the researchers and farmers. Green manures have been studied as a potential control strategy for soil-borne diseases by increasing microbial competition and antagonism (Ochiai et al., 2007; Kamil et al., 2009; Larkin, 2013), while at the same time reducing the inoculum potential through germination and lysis of propagules in the soil (Larkin and Griffin, 2007). Besides reduction in soil borne inoculum of phytopathogenic diseases, green manures offer substantial benefits to soil including increased organic matter and nutrients (Pung et al., 2004), improved soil structure (Mandal et al., 2003), weed suppression (Al-Khatib et al., 1997) and erosion control (Blackshaw et al., 2001). Green manures may influence pathogens directly through breakdown of glucosinolates or by releasing fungitoxic compounds such as avenacin, saponins or allyl isothiocyanate (Mayton et al., 1996) and also affecting soilborne pathogens indirectly by influencing indigenous microbial populations (Manici et al., 2004).

The use of Sesbania spp. in particular and other related plants in general as cover crop, crop rotation or green manure crops for reducing soil-borne pathogens and diseases has been receiving increased attention in recent years (Kumar et al., 2014). Under the present investigation, effect of 8 dominant fungal decomposers i.e., Aspergillus niger, Aspergillus flavus, Aspergillus fumigatus, Trichoderma harzianum, Penicillium citrinum, Penicillium rubrum, Cladosporium cladosporioides and Curvularia lunata on radial growth and sclerotia production of three soil borne pathogens viz., Sclerotium rolfsii, Rhizoctonia solaniand Sclerotinia sclerotiorum was evaluated.

\section{Materials and Methods}

Isolation of dominant fungal decomposers: The fungal community associated with decomposition of Sesbania aculeata L. green manure were observed, isolated and maintained by following three methods viz., direct observation method (Garrett, 1981), damp chamber incubation method (Boedijn, 1956) and dilution plate technique (Warcup, 1960). The green manure decomposing fungi were identified and enlisted (Kumar et al., 2011). Out of total 44 fungal species observed during the decomposition period, eight potential decomposing fungi viz., Aspergillus niger, Aspergillus flavus, Aspergillus fumigatus, Trichoderma harzianum, Penicillium citrinum, Penicillium rubrum, Cladosporium cladosporioides and Curvularia lunata were recorded as dominant fungal decomposers (Kumar et al., 2011). These eight dominant fungal decomposers were cultured on potato dextrose agar plates at $28 \pm 2^{\circ} \mathrm{C}$ for further studies.

Collection and maintenance of soil borne plant pathogens: Three soil-borne plant pathogens viz., Sclerotium rolfsii (ITCC 5518), Rhizoctonia solani (ITCC 4110) and Sclerotinia sclerotiorum (ITCC 6094) were selected for the study and collected from Indian Type Culture Collection (ITCC), Indian Agriculture Research Institute, New Delhi. These three test pathogens were sub-cultured on potato dextrose agar medium at $25 \pm 2^{\circ} \mathrm{C}$ for further research activities.

Effects of green manure amendment on viability of sclerotia of Sclerotium rolfsii, Rhizoctonia solani and Sclerotinia sclerotiorum: A large number of sclerotia of Sclerotium rolfsii, Rhizoctonia solani and Sclerotinia sclerotiorum were produced on PDA medium and collected. One hundred gram, 2.5-3.0 cm long pieces of green manure (Sesbania aculeata L.) was mixed into pots containing $2.5 \mathrm{~kg}$ sterilized field soil and two hundred sclerotia of a test pathogen were incorporated into the soil containing green manure. Similarly, control sets were prepared having no green manure. Three replication of each treatment were prepared. All these pots were moistened time to time by adding some sterilized water to facilitate decomposition of green manure and kept for thirty days. The sclerotia were collected from these pots after filtering the soil through muslin cloth. The numbers of sclerotia were counted and their viability was tested by transferring them on PDA medium and incubated at $25+2^{\circ} \mathrm{C}$ for seven days.

Dual Culture Technique: The dominant fungal decomposers were evaluated against three test pathogens in laboratory by dual culture technique as described by Morton and Stroube (1955) to screen out most efficacious fungi. Petri dishes $(90 \mathrm{~mm})$ containing PDA medium were inoculated with $5 \mathrm{~mm}$ diameter mycelial discs of 7 days old vigorously growing colonies of dominant fungi and test pathogens at equal distance from periphery. Inoculated plates were incubated at $25+2^{\circ} \mathrm{C}$ in $\mathrm{BOD}$ incubator and the radial growth of test pathogens was measured at 24, 48, 72 and $96 \mathrm{hr}$ 
after incubation. Control sets without decomposing fungi were maintained and each treatment was replicated six times. Percent inhibition in growth of test pathogens was calculated by the following formula:

$\begin{aligned} & \text { Percent inhibition } \\ & \text { in radial growth }\end{aligned}=\frac{\begin{array}{l}\text { Growth in control }(\mathrm{mm})- \\ \text { Growth in treatment }(\mathrm{mm})\end{array}}{\text { Growth in control }(\mathrm{mm})} \times 100 \ldots(1)$

From the zone of interaction between the antagonist fungal decomposers and test pathogens in dual culture plate, the mycelial mats were gently lifted with a needle and put in a drop of cotton blue on a microscopic slide and observed under microscope for hyphal interaction, hyphal interference and mycoparasitism.

The rest three Petri dishes were kept for further incubation and the effect of dominant fungal decomposers on sclerotia production by test pathogens in dual culture was studied. The number of sclerotia produced by the test pathogens in dual culture was counted after 21 days of incubation at $25 \pm 2^{\circ} \mathrm{C}$, and percent reduction in sclerotia was determined by the following formula :

$$
\begin{aligned}
& \% \text { reduction } \\
& \text { in sclerotia }
\end{aligned}=\frac{\begin{array}{c}
\text { Sclerotia produced in control }- \\
\text { sclerotia produced in treatment }
\end{array}}{\text { Sclerotia produced in control }} \times 100 \ldots \text { (2) }
$$

Effects of volatile metabolites of dominant fungal decomposers on radial growth and sclerotia production of test pathogens: The isolates of dominant fungal decomposers were evaluated in laboratory to screen out the most efficacious fungi, which inhibit growth of soil-borne pathogens by producing volatile substances following the technique described by Dennis and Webster (1971a). The dominant fungi were centrally inoculated in Petri dishes $(90 \mathrm{~mm})$ by placing $5 \mathrm{~mm}$ discs taken from 5-day-old culture on the PDA plates and incubated at $25 \pm 2^{\circ} \mathrm{C}$ for a week. After incubation, the lid of each Petri dish was replaced by the same size of bottom plate containing $25 \mathrm{ml}$ of PDA medium inoculated centrally with $5 \mathrm{~mm}$ disc of test pathogen. Petri dishes with PDA medium without dominant fungi at lower lid and inoculated by test pathogens were maintained as control. Three replications were maintained for each treatment. The pairs of each Petri dish were sealed together with paraffin tape and incubated at $25 \pm 2^{\circ} \mathrm{C}$. Colony diameter of the pathogen was measured at 24, 48, 72 and $96 \mathrm{hr}$ after incubation and the inhibition in mycelial growth was calculated by formula number 1 .

To study the effect of volatile metabolites of dominant fungal decomposers on sclerotia production by test pathogens, the number of sclerotia was counted after 21 days of incubation at $25 \pm 2^{\circ} \mathrm{C}$. The effect of dominant fungi on sclerotia production by test pathogens in terms of percent reduction in sclerotia was estimated by formula number 2 .

Effects of non-volatile metabolites of dominant fungal decomposers on radial growth and sclerotia production of test pathogens: The effect of non-volatile substances produced by the dominant fungal decomposers was determined by following the method described by Dennis and Webster (1971b). The dominant fungi were inoculated in $100 \mathrm{ml}$ sterile potato dextrose broth in $250 \mathrm{ml}$ conical flasks. Inoculated flasks were incubated at $25 \pm 2^{\circ} \mathrm{C}$ for 15 days. The culture was filtered through Millipore filter and culture filtrate was added to molten PDA medium $\left(40^{\circ} \mathrm{C}\right)$ to obtain a final concentration of $50 \%(\mathrm{v} / \mathrm{v})$. The medium was poured into the Petri dishes at $25 \mathrm{ml} \mathrm{plate}^{-1}$ in three replications and inoculated after solidification with $5 \mathrm{~mm}$ discs of test of pathogens. Control plates were maintained without amending the culture filtrate. Petri dishes were sealed with paraffin tape and incubated at $25 \pm 2^{\circ} \mathrm{C}$. After $24,48,72$ and $96 \mathrm{hr}$, the radial growth of test pathogens was measured and percent inhibition was calculated by formula number 1 .

To study the effect of non-volatile metabolites of dominant fungal decomposers on sclerotia production by test pathogens, the number of sclerotia was counted after 21 days of incubation at $25 \pm 2^{\circ} \mathrm{C}$. The effect of dominant fungal decomposers on sclerotia production by the test pathogens was estimated in terms of percent reduction in sclerotia using formula number 2.

Statistical analysis : All the data were analyzed statistically in a complete randomized design (CRD). Least significant differences were (LSD at 1\%) used to compare the treatment means (Gomez and Gomez, 1984).

\section{Results and Discussion}

Effect of green manure amendment on sclerotial viability of Sclerotium rolfsii, Rhizoctonia solani and Sclerotinia sclerotiorum: The amendment of Sesbania aculeata green manure caused maximum reduction $(40.0 \%)$ in the sclerotial bodies of Sclerotium rolfsii as against $13.0 \%$ and $8.17 \%$ in control sets having un-autoclaved and autoclaved soils, respectively. Similarly, reduction in sclerotia of Rhizoctonia solani was $36.0 \%$ in green manure amended pots as against $18.0 \%$ and $10.67 \%$ in control sets having un-autoclaved and autoclaved soils, respectively, whereas reduction in sclerotia of Sclerotinia sclerotiorum was $36.50 \%$ in green manure amended pots as against $20.33 \%$ and $10.50 \%$ in control sets having un-autoclaved and autoclaved soils, respectively (Table 1).

The amendment of green manures in pots might have encouraged the growth and development of soil microbiota, which suppressed sclerotia germination or antagonized the mycelium of sclerotial pathogens after its germination (Coventry et al., 2006). Reduction in sclerotial bodies with green manure amendment might also be due to parasitism of sclerotia by dominant fungal decomposers during decomposition of Sesbania 
Table 1: Effect of green manure amendment on viability of sclerotia of test pathogens

\begin{tabular}{llll}
\hline Test pathogen & Number of sclerotia mixed $^{*}$ & Number of sclerotia collected $^{*}$ & Reduction in number (\%) $^{\text {Sclerotium rolfsii }}$ \\
Green Manure & 200 & 120.00 & 40.00 \\
Control (Un autoclaved) & 200 & 174.00 & 13.00 \\
Control (Autoclaved) & 200 & 183.66 & 8.17 \\
Rhizoctonia solani & & & 36.00 \\
Green manure & 200 & 128.00 & 18.00 \\
Control (Un autoclaved) & 200 & 164.00 & 10.67 \\
Control (Autoclaved) & 200 & 178.66 & 36.50 \\
Sclerotinia sclerotiorum & & & 20.33 \\
Green Manure & 200 & 127.00 & 10.50 \\
Control (Un autoclaved) & 200 & 159.33 & \\
Control (Autoclaved) & 200 & 179.00 & \\
\hline
\end{tabular}

*Values are mean of three replicates

Table 2: Effect of dominant fungal decomposers on the sclerotia production by test pathogens by dual culture technique after 21 days of incubation

\begin{tabular}{|c|c|c|c|c|c|c|}
\hline \multirow[t]{2}{*}{ Dominant Fungi } & \multicolumn{2}{|c|}{ Sclerotium rolfsii } & \multicolumn{2}{|c|}{ Rhizoctonia solani } & \multicolumn{2}{|c|}{ Sclerotinia sclerotiorum } \\
\hline & $\begin{array}{l}\text { Number of } \\
\text { sclerotia produced }^{*}\end{array}$ & $\begin{array}{l}\% \text { reduction } \\
\text { of sclerotia }\end{array}$ & $\begin{array}{l}\text { Number of } \\
\text { sclerotia produced }\end{array}$ & $\begin{array}{l}\text { \% reduction } \\
* \text { of sclerotia }\end{array}$ & $\begin{array}{l}\text { Number of } \\
\text { sclerotia produced }^{*}\end{array}$ & $\begin{array}{l}\% \text { reduction } \\
\text { of sclerotia }\end{array}$ \\
\hline Aspergillus niger & 48.00 & 75.60 & 21.66 & 82.67 & 12.00 & 77.64 \\
\hline Aspergillus flavus & 95.66 & 51.36 & 49.00 & 60.80 & 14.66 & 72.68 \\
\hline Aspergillus fumigatus & 122.33 & 37.80 & 89.66 & 28.27 & 23.00 & 57.14 \\
\hline Trichoderma harzianum & 26.66 & 86.44 & 14.33 & 88.54 & 6.33 & 88.20 \\
\hline Penicillium citrinum & 42.00 & 78.64 & 37.33 & 70.14 & 12.66 & 76.40 \\
\hline Penicillium rubrum & 95.33 & 51.53 & 82.00 & 34.40 & 14.66 & 72.67 \\
\hline Cladosporium cladosporioides & 159.00 & 19.15 & 111.00 & 11.20 & 16.00 & 70.18 \\
\hline Curvularialunata & 165.00 & 16.10 & 102.00 & 18.40 & 29.00 & 45.96 \\
\hline Control & 196.66 & - & 125.00 & - & 53.66 & - \\
\hline $\mathrm{SEm} \pm$ & 4.94 & - & 3.56 & - & 1.72 & - \\
\hline $\operatorname{LSD}(P=0.01)$ & 20.09 & - & 14.39 & - & 6.99 & - \\
\hline
\end{tabular}

*Values are mean of three replications

aculeata in pots. Parasitism was thought to be accompanied by production of lytic enzymes rather than antibiosis. Coiling and penetration of sclerotia of $S$. rolfsii by Trichoderma harzianum were observed by Benhamou and Chet (1996). Reduction in sclerotia of soil-borne phytopathogens viz., R. solani, S. rolfsii and $S$. sclerotiorum, in green manure amended soil, is in the agreement with the study of Kamil et al. (2009), who reported significant reduction in sclerotia of two sclerotial pathogens viz., $R$. solaniand S. rolfsii due to the effect of green manuring.

Dual culture technique: All the fungal decomposers inhibited the mycelial growth of soil-borne plant pathogens significantly over control, in dual culture. Among 8 fungal decomposers, Trichoderma harzianum inhibited the growth of Sclerotium rolfsii upto $49.95 \%$, which was significantly superior over all the other fungal decomposers. This was followed by Penicillium citrinum (46.20\%) and Aspergillus niger (33.16\%), while Curvularia lunata (20.35\%) showed the lowest growth inhibition of Sclerotium rolfsii. Almost similar pattern was observed in test pathogens;
Rhizoctonia solani and Sclerotinia sclerotiorum (Fig. 1). The maximum growth inhibition of Rhizoctonia solani was caused by Trichoderma harzianum (47.62\%) followed by Penicillium citrinum (45.13\%) and Aspergillus niger (42.70\%), whereas Aspergillus fumigatus $(24.72 \%)$ caused minimum growth inhibition of Rhizoctonia solani. The maximum growth inhibition of Sclerotinia sclerotiorum was caused by Trichoderma harzianum (57.83\%) followed by Aspergillus niger (50.22\%) and Penicillium citrinum (47.01\%), whereas Aspergillus fumigatus caused minimum inhibition of Sclerotinia sclerotiorum growth (28.14\%).

All the decomposer fungal antagonists viz., Trichoderma harzianum, Penicillium citrinum, Aspergillus niger, Aspergillus flavus, Aspergillus fumigatus, Penicillium rubrum, Cladosporium cladosporioides and Curvularia lunata inhibited mycelial growth of the test pathogens. T. harzianum inhibited maximum mycelial growth of the pathogens at 4 days of incubation. The mechanism of inhibition might be competition for food and space. P. citrinum ranked second best antagonist after $T$. harzianum at 4 days of 


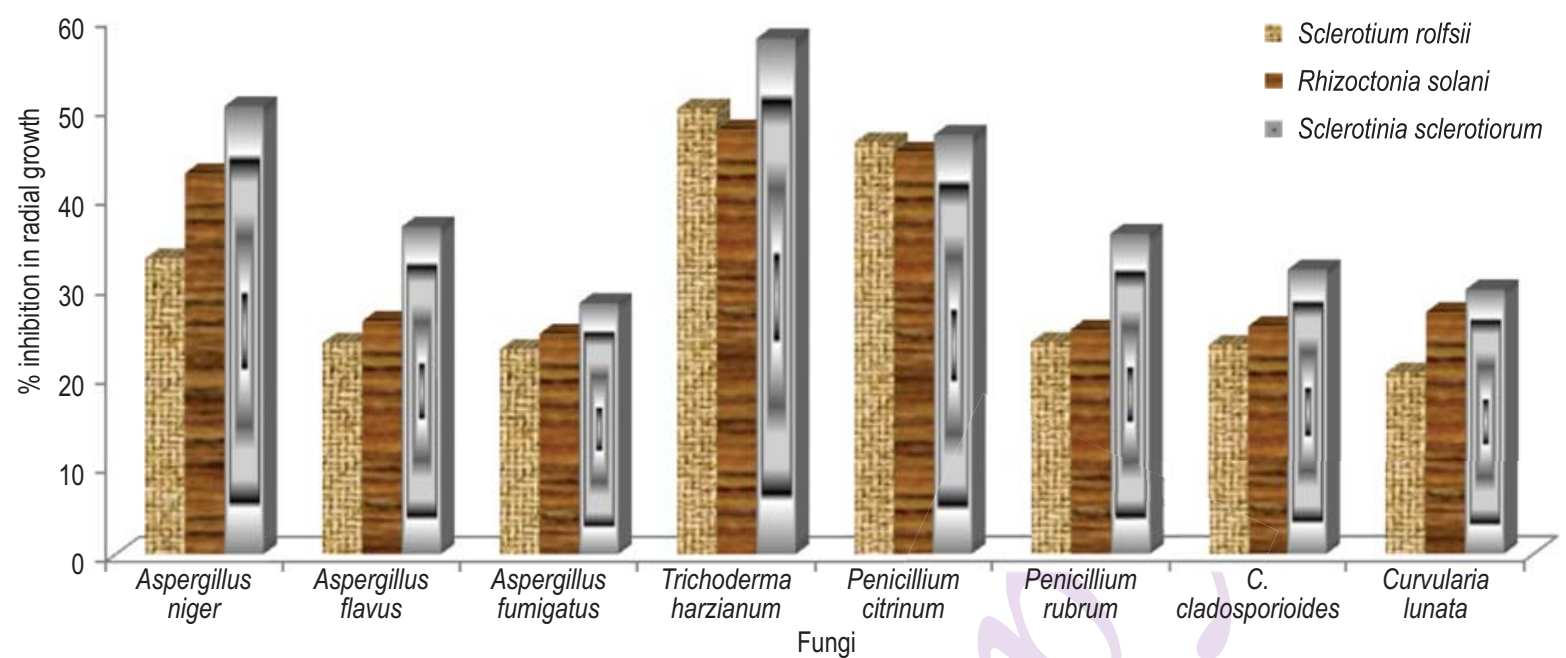

Fig. 1 : Effect of dominant fungal decomposers on radial growth of test pathogens viz., Sclerotium rolfsii, Rhizoctonia solaniand Sclerotinia sclerotiorum in dual culture

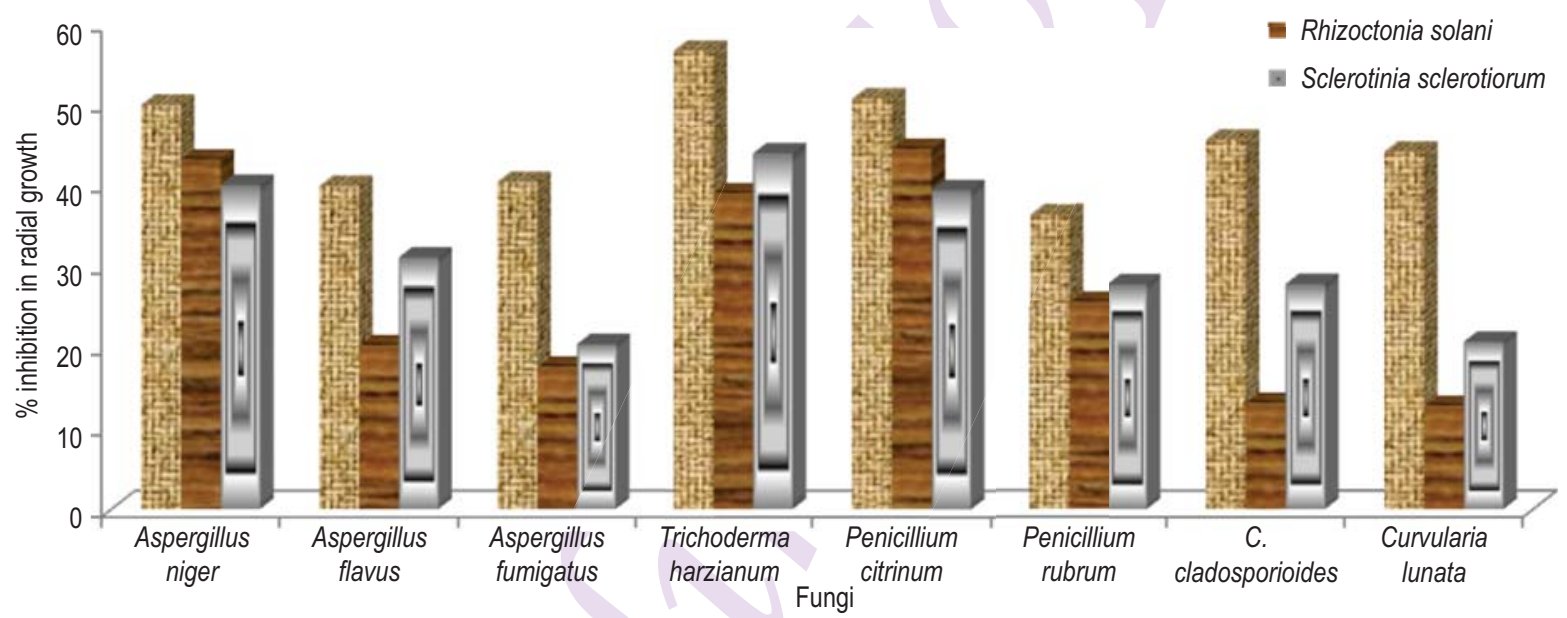

Fig. 2 : Effect of volatile metabolites of dominant fungal decomposers on radial growth of test pathogens viz., Sclerotium rolfsii, Rhizoctonia solani and Sclerotinia sclerotiorum

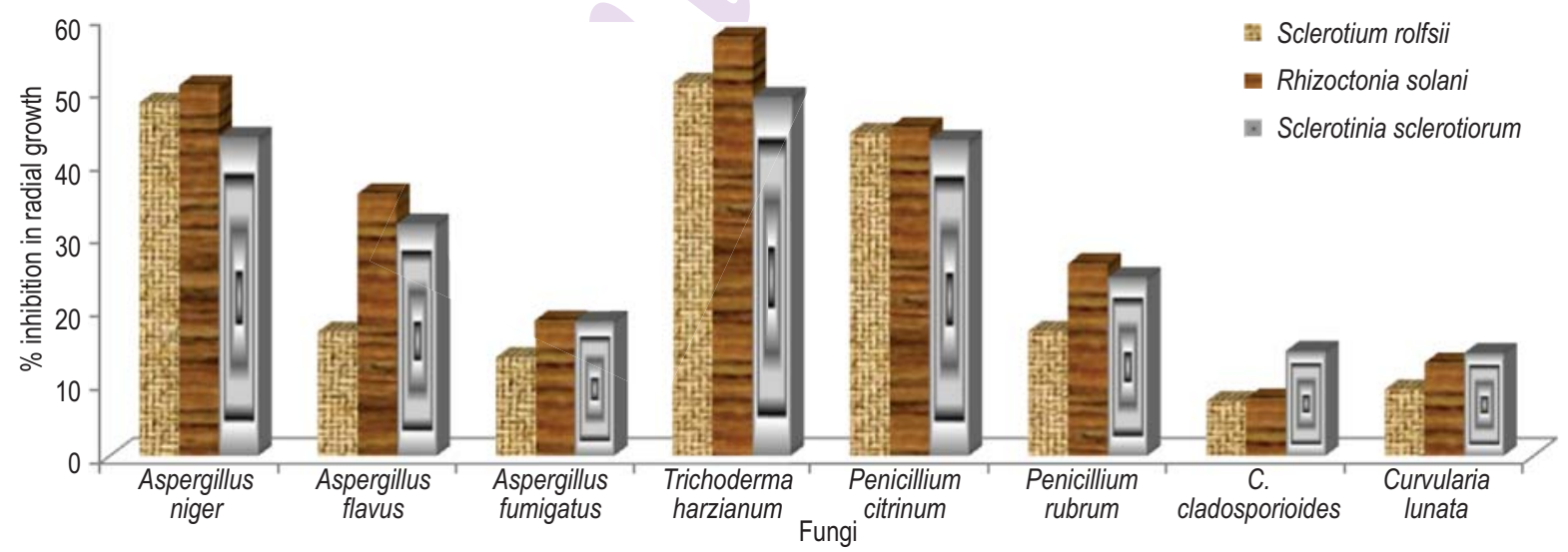

Fig. 3 : Effect of non-volatile metabolites of dominant fungal decomposers on radial growth of test pathogens viz., Sclerotium rolfsii, Rhizoctonia solani and Sclerotinia sclerotiorum 
Table 3: Effect of volatile metabolites of dominant fungal decomposers on the sclerotia production by the test pathogens after 21 days of incubation

\begin{tabular}{|c|c|c|c|c|c|c|}
\hline \multirow[t]{2}{*}{ Dominant Fungi } & \multicolumn{2}{|c|}{ Sclerotium rolfsii } & \multicolumn{2}{|c|}{ Rhizoctonia solani } & \multicolumn{2}{|c|}{ Sclerotinia sclerotiorum } \\
\hline & $\begin{array}{l}\text { Number of } \\
\text { sclerotia produced }^{*}\end{array}$ & $\begin{array}{l}\% \text { reduction } \\
\text { of sclerotia }\end{array}$ & $\begin{array}{l}\text { Number of } \\
\text { sclerotia produced }^{*}\end{array}$ & $\begin{array}{l}\% \text { reduction } \\
\text { of sclerotia }\end{array}$ & $\begin{array}{l}\text { Number of } \\
\text { sclerotia produced }\end{array}$ & $\begin{array}{l}\% \text { reduction } \\
\text { of sclerotia }\end{array}$ \\
\hline Aspergillus niger & 38.33 & 80.51 & 26.33 & 78.94 & 13.66 & 74.54 \\
\hline Aspergillus flavus & 63.00 & 67.96 & 56.33 & 54.94 & 29.00 & 45.96 \\
\hline Aspergillus fumigatus & 132.66 & 32.54 & 70.00 & 44.00 & 39.00 & 27.20 \\
\hline Trichoderma harzianum & 9.00 & 95.42 & 8.00 & 93.60 & 4.66 & 91.32 \\
\hline Penicillium citrinum & 31.00 & 84.24 & 10.00 & 92.00 & 17.33 & 67.70 \\
\hline Penicillium rubrum & 43.33 & 77.97 & 28.33 & 77.34 & 29.33 & 45.34 \\
\hline Cladosporium cladosporioides & 78.66 & 60.00 & 40.00 & 68.00 & 14.66 & 72.68 \\
\hline Curvularia lunata & 91.33 & 53.56 & 63.00 & 49.60 & 45.33 & 15.52 \\
\hline Control & 196.66 & - & 125.00 & - & 53.66 & - \\
\hline SEm \pm & 3.64 & - & 2.06 & - & 2.24 & - \\
\hline $\operatorname{LSD}(P=0.01)$ & 14.82 & - & 8.40 & - & 9.11 & - \\
\hline
\end{tabular}

*Values are the mean of three replications

incubation. Trichoderma viride, T. harzianum, Gliocladium roseum, Penicillium citrinum, Aspergillus niger and Curvularia lunata were reported by several workers as the best antagonists for growth inhibition of several soil borne, seed borne and foliar plant pathogens (Dubey et al., 2007; Kamil et al., 2009; Ahmed and Upadhyay, 2009; Prabhakaran et al., 2015).

Colonial interaction between the pathogens and the dominant fungi showed inhibition zone as a result of the production of antibiotics. Coiling and penetration of hyphae of $R$. solani and S. rolfsii by Trichoderma harmatum and T. harzianum, and appressorium-like structures and hooks, were observed by Elad et al. (1983). The overgrowth is achieved when a fungus exhibits higher growth rate, tolerance against metabolites produced by the other fungus (Mathivanan et al., 2000) and higher capacity of antibiotic production.

In dual culture, 21 days after incubation, Trichoderma harzianum caused the maximum reduction $(86.44 \%)$ in sclerotia of Sclerotium rolfsii, followed by Penicillium citrinum (78.64\%) and Aspergillus niger (75.60\%), whereas Curvularia lunata showed minimum reduction (16.10\%) in sclerotia of Sclerotium rolfsii. The maximum reduction in sclerotia of Rhizoctonia solani was caused by Trichoderma harzianum (88.54\%) followed by Aspergillus niger (82.67\%) and Penicillium citrinum (70.14\%), while Cladosporium cladosporioides caused minimum reduction $(11.20 \%)$ in sclerotia of Rhizoctonia solani. The maximum reduction in sclerotia of Sclerotinia sclerotiorum was caused by Trichoderma harzianum (88.20\%) followed by Aspergillus niger (77.64\%) and Penicillium citrinum $(76.40 \%)$; and minimum reduction $(45.96 \%)$ in sclerotia of Sclerotinia sclerotiorum was caused by Curvularia lunata (Table 2 ).

The sclerotia production of the test pathogens in dual culture after 21 days of incubation was reduced significantly by all the fungal decomposers. The sclerotial bodies might be reduced due to antibiotic production and competition for food and space. $T$. harzianum, $P$. citrinum and $A$. niger caused maximum reduction in sclerotia of test pathogens viz., Sclerotium rolfsii, Rhizoctonia solani and Sclerotinia sclerotiorum. These results are in agreement with Dutta and Das (2002) who reported 94.2\% reduction in sclerotia of tomato isolate of $S$. rolfsii by dual culture technique with Trichoderma harzianum. Amin et al. (2010 a) reported that $T$. viride ( $T v-1$ isolate) was most effective in reducing sclerotia production ( $83.75 \%$ in R. solani, $80.18 \%$ in S. rolfsii and $70.15 \%$ in S. sclerotiorum) of various soil borne pathogens. Rekha et al. (2012) reported that three species of Trichoderma viz., Trichoderma virens (Tri-12 and Tri-15), Trichoderma viride (Tri-13) and Trichoderma harzianum (Tri-44) were most efficient in reducing the number of sclerotial bodies of $S$. rolfsii, the collar rot pathogen of ground nut, in dual culture plate.

Effect of the volatile metabolites of dominant fungal decomposers on radial growth and sclerotia production of the test pathogens: The volatile metabolites released from the cultures of dominant fungal decomposers inhibited radial growth of test pathogens viz., Sclerotium rolfsii, Rhizoctonia solani and Sclerotinia sclerotiorum. The means of the radial growth inhibition indicated that volatile metabolites produced by Trichoderma harzianum caused maximum inhibition in growth of Sclerotium rolfsii (56.64\%) followed by Penicillium citrinum (50.72\%) and Aspergillus niger (49.95\%), whereas Penicillium rubrum caused minimum inhibition (36.38\%) in Sclerotium rolfsii growth. The percent inhibition in growth of Rhizoctonia solani by volatile metabolites produced by Penicillium citrinum (44.96\%) was found to be maximum. This was followed by Aspergillus niger (43.15\%) and Trichoderma harzianum (38.96\%), while Aspergillus fumigatus, Curvularia lunata and Cladosporium cladosporioides caused little inhibition in growth of this pathogen. The maximum inhibition in growth of Sclerotinia sclerotiorum was caused by 
Table 4: Effect of non-volatile metabolites of dominant fungal decomposers on the sclerotia production by test pathogens after 21 days of incubation

\begin{tabular}{|c|c|c|c|c|c|c|}
\hline \multirow[t]{2}{*}{ Dominant Fungi } & \multicolumn{2}{|c|}{ Sclerotium rolfsii } & \multicolumn{2}{|c|}{ Rhizoctonia solani } & \multicolumn{2}{|c|}{ Sclerotinia sclerotiorum } \\
\hline & $\begin{array}{l}\text { Number of } \\
\text { sclerotia produced* }\end{array}$ & $\begin{array}{l}\% \text { reduction } \\
\text { of sclerotia }\end{array}$ & $\begin{array}{l}\text { Number of } \\
\text { sclerotia produced* }\end{array}$ & $\begin{array}{l}\% \text { reduction } \\
\text { of sclerotia }\end{array}$ & $\begin{array}{l}\text { Number of } \\
\text { sclerotia produced* }\end{array}$ & $\begin{array}{l}\% \text { reduction } \\
\text { of sclerotia }\end{array}$ \\
\hline Aspergillus niger & 46.66 & 76.27 & 34.33 & 72.54 & 16.33 & 69.57 \\
\hline Aspergillus flavus & 74.33 & 62.20 & 41.66 & 66.67 & 34.00 & 36.64 \\
\hline Aspergillus fumigatus & 84.00 & 57.29 & 90.00 & 28.00 & 17.33 & 67.70 \\
\hline Trichoderma harzianum & 24.66 & 87.46 & 25.33 & 79.74 & 8.00 & 85.10 \\
\hline Penicillium citrinum & 45.00 & 77.12 & 42.33 & 66.14 & 10.33 & 80.75 \\
\hline Penicillium rubrum & 99.00 & 49.66 & 64.66 & 48.27 & 35.33 & 34.16 \\
\hline Cladosporium cladosporioides & 101.66 & 48.31 & 50.66 & 59.47 & 26.66 & 50.32 \\
\hline Curvularia lunata & 81.66 & 58.48 & 94.00 & 24.80 & 18.33 & 65.84 \\
\hline Control & 196.66 & - & 125.00 & - & 53.66 & - \\
\hline SEm \pm & 4.55 & - & 2.46 & - & 1.67 & - \\
\hline $\operatorname{LSD}(P=0.01)$ & 18.52 & - & 10.00 & - & 6.80 & - \\
\hline
\end{tabular}

*Values are mean of three replications

volatile metabolites of Trichoderma harzianum (43.95\%) followed by Aspergillus niger (40.02\%) and Penicillium citrinum (39.36\%); and minimum inhibition $(20.42 \%)$ of this pathogen was caused by Aspergillus fumigatus (Fig. 2).

The antagonistic fungal decomposers inhibited the growth of Sclerotium rolfsii, Rhizoctonia solani and Sclerotinia sclerotiorum through the production of volatile substances. After 4 days of incubation, T. harzianum caused maximum growth inhibition, which might be due to production of higher amount of volatile compounds by $T$. harzianum. The volatile compounds produced by several fungal species including green manure decomposing fungi viz., Trichoderma viride, T. harzianum, Gliocladium roseum, Penicillium citrinum, Aspergillus niger and Curvularia lunata have been proved to be inhibitory against soil borne plant pathogens viz., R. solani and S. rolfsii (Kamil et al., 2009; Srinivasa et al., 2014). The growth of test pathogen in the volatile metabolites of dominant fungi depends upon its ability to tolerate toxicity of fungal growth products. Dennis and Webster (1971 a) identified a volatile antibiotic produced by Trichoderma $\mathrm{sp}$. that inhibited growth of $R$. solani and other test fungi, with activity being related to 'coconut' odour.

The maximum reduction in sclerotia of Sclerotium rolfsii was caused by volatile metabolites of Trichoderma harzianum (95.42\%) followed by Penicillium citrinum (84.24\%) and Aspergillus niger ( $80.51 \%)$, while minimum reduction in sclerotia was caused by Aspergillus fumigatus (32.54\%). The maximum reduction in sclerotia of Rhizoctonia solani was caused by volatile metabolites of Trichoderma harzianum (93.60\%) followed by Penicillium citrinum (92.0\%) and Aspergillus niger (78.94\%), while minimum reduction in sclerotia was caused by Aspergillus fumigatus (44.0\%). The maximum reduction in sclerotia of Sclerotinia sclerotiorum was caused by volatile metabolites of Trichoderma harzianum (91.32\%) followed by Aspergillus niger
(74.54\%) and Cladosporium cladosporioides (72.68\%), whereas minimum reduction $(15.52 \%)$ in sclerotia of this pathogen was caused by Curvularia lunata (Table 3 ).

The volatile and non-volatile metabolites of Trichoderma spp. have also been reported to reduce sclerotia germination, sclerotia production and sclerotia length of Sclerotinia sclerotiorum by Kapil and Kapoor (2005). They reported that maximum reduction in number of sclerotia was observed in T. viride B $(78.68 \%)$, whereas maximum reduction in length of sclerotia was observed with $T$. viride $E(59.27 \%)$ due to the effects of volatile metabolites released by the biocontrol agent. Amin et al. (2010 b) reported that volatile metabolites from $T$. viride $(T v-2)$ accounted for maximum reduction in sclerotia production $(65.65 \%)$ of $R$. solani, whereas volatile metabolites from $T$. viride $(T v-1)$ caused maximum reduction in sclerotia production in S. rolfsii (48.19\%) and S. sclerotiorum (78.87\%).

Effect of the non-volatile metabolites of dominant fungal decomposers on radial growth and sclerotia production of the test pathogens: All the fungal decomposers tested for nonvolatile metabolites, were found to reduce the radial growth of soil borne pathogens over control. The means of radial growth inhibition indicated that non-volatile metabolites of Trichoderma harzianum caused maximum growth inhibition of Sclerotium rolfsii $(51.04 \%)$ followed by Aspergillus niger (48.30\%) and Penicillium citrinum (44.15\%); and minimum growth inhibition of this pathogen was caused by Cladosporium cladosporioides $(7.48 \%)$. The maximum growth inhibition of Rhizoctonia solani was caused by non-volatile metabolites of Trichoderma harzianum (57.30\%) followed by Aspergillus niger (50.68\%) and Penicillium citrinum (44.92\%), while minimum growth inhibition was caused by Cladosporium cladosporioides (7.84\%). The maximum growth inhibition of Sclerotinia sclerotiorum was caused by non-volatile metabolites of Trichoderma harzianum 
(49.10\%) followed by Aspergillus niger (43.62\%) and Penicillium citrinum $(43.20 \%)$, while minimum growth inhibition (14.10\%) was caused by Curvularia lunata (Fig. 3).

The antagonistic fungal decomposers inhibited the radial growth of pathogens significantly by the production of non-volatile antibiotic substances. Maximum growth inhibition of the pathogens was observed in T. harzianum, which was significantly higher with next effective antagonist. This showed that nonvolatile substances produced by $T$. harzianum were more inhibitory to Sclerotium rolfsii, Rhizoctonia solani and Sclerotinia sclerotiorum than other antagonistic fungi. These results are in good agreement of Kamil et al. (2009) who reported that $T$. harzianum, Penicillium citrinum, Aspergillus niger caused maximum growth inhibition of $R$. solani and $S$. rolfsii through production of non-volatile substances. The efficiency of nonvolatile substances produced by different fungi for inhibition in radial growth of plant pathogens was tested by several workers (Dubey et al., 2007; Khilari et al., 2008; Srinivasa et al., 2014). T. harzianum and $T$. viride have been reported to cause maximum growth inhibition of Sclerotinia sclerotiorum through production of non-volatile metabolites, volatile metabolites and in dual culture (Kapil and Kapoor, 2005).

The non-volatile metabolites of dominant fungal decomposers reduced sclerotia production of test pathogens viz., Sclerotium rolfsii, Rhizoctonia solani and Sclerotinia sclerotiorum after 21 days of incubation, significantly (Table 4). The maximum reduction in sclerotia of Sclerotium rolfsii was caused by nonvolatile metabolites of Trichoderma harzianum (87.46\%) followed by Penicillium citrinum (77.12\%) and Aspergillus niger (76.27\%); and minimum reduction in sclerotia of this pathogen was caused by Cladosporium cladosporioides (48.31\%). The maximum reduction in sclerotia of Rhizoctonia solani was caused by nonvolatile metabolites of Trichoderma harzianum (79.74\%) followed by Aspergillus niger (72.54\%) and Aspergillus flavus (66.67\%), whereas minimum reduction in sclerotia of this pathogen was caused by Curvularia lunata (24.80\%). The maximum reduction in sclerotia of Sclerotinia sclerotiorum was caused by non-volatile metabolites of Trichoderma harzianum (85.10\%) followed by Penicillium citrinum (80.75\%) and Aspergillus niger (69.57\%), whereas minimum reduction in sclerotia was caused by Penicillium rubrum (34.16\%).

The sclerotia production of soil borne pathogens viz., $S$. rolfsii, $R$. solani and S. sclerotiorum was reduced significantly through non-volatile metabolites of fungal decomposers. The results of the study are in confirmation with Prasad and Kumar (2011), who reported that non-volatile compound produced by Trichoderma spp. have inhibitory effects on germination or viability of sclerotia of $R$. solani. They suggested that TN3 isolate of Trichoderma spp. can reduce the viability of sclerotia upto $62.04 \%$. The non-volatile metabolites of Trichoderma spp. have also been reported to reduce sclerotia germination of Sclerotinia sclerotiorum by Kapil and Kapoor (2005). In their study, maximum inhibition of sclerotia germination was observed in T. viride B $(61.96 \%)$ due to its non-volatile metabolites. Species of soil fungi viz., Trichoderma harzianum, T. koningii, T. viride, T. virens, Trichoderma species, Aspergillus niger, Aspergillus flavus, Cladosporium cladosporioides and Penicillium citrinum have been reported for the contribution to the successful biological control of another soil-borne fungal pathogen viz., Fusarium oxysporum f. sp. lycopersici in colony interaction, volatile and non-volatile metabolites studies (Ahmed and Upadhayay, 2009).

The present study highlighted the effectiveness of dominant fungal decomposers of green manure in controlling the soil borne pathogens. All eight fungal decomposers were found to contribute in controling soil borne pathogens. Overall $T$. harzianum, Aspergillus niger and Penicillium citrinum proved as potential bio-control agents against all the soil borne plant pathogens viz., S. rolfsii, R. solaniand S. sclerotiorum.

\section{Acknowledgments}

The authors are sincerely thankful to the Head, Department of Mycology and Plant Pathology, Institute of Agricultural Sciences, Banaras Hindu University, Varanasi221005 for providing necessary research facilities. Our sincere thanks are also due to the University Grant Commission, Government of India for the financial support.

\section{References}

Ahmed, M. and R.S. Upadhyay: Rhizosphere fungi of tomato: their effect on seed germination, seedling growth and the causal agent of wilt of tomato. J. Mycopathol. Res., 47, 99-110 (2009).

Al-Khatib, K., C. Libbey and R. Boydston: Weed suppression with Brassica green manure crops in green pea. Weed Science, 45 , 439-445(1997).

Amin, F., V.K. Razdan, F.A. Mohiddin, K.A. Bhat and P.A. Sheikh: Effect of volatile metabolites of Trichoderma species against seven fungal plant pathogens in-vitro. J. Phytol., 2, 34-37 (2010a).

Amin, F., V.K. Razdan, F.A. Mohiddin, K.A. Bhat and S. Banday: Potential of Trichoderma species as biocontrol agents of soil borne fungal propagules. J. Phytol., 2, 38-41 (2010b).

Benhamou, N. and I. Chet: Parasitism of sclerotia of Sclerotium rolfsii by Trichoderma harzianum ultrastructural and cytochemical aspects of interaction. Phytopathol., 86, 405-415 (1996).

Blackshaw, R.E., J.R. Moyer, R.C. Doram and A.L. Boswell: Yellow sweet clover green manure and its residues effectively suppress weeds during fallow. Weed Science, 49, 406-413 (2001).

Boedijn, K.B.: Trypon blue as a stain for fungi. Stain Technol., 31,115-116 (1956).

Coventry, E., R. Noble, A. Mead, F.R. Martin, J.A. Perez and J.M. Whipps: Allium white rot suppression with composts and Trichoderma viride in relation to sclerotia viability. Phytopathol., 96, 1009-1020 (2006).

Dennis, C. and J. Webster: Antagonistic properties of species groups of Trichoderma. II. Production of volatile antibiotics. Trans. Br. Mycol. 
Soc., 57, 41-48(1971a).

Dennis, C. and J. Webster: Antagonistic properties of species groups of Trichoderma. I. Production of non-volatile antibiotics. Trans. Br. Mycol. Soc., 57, 25-39 (1971b).

Dubey, S.C., M. Suresh and B. Singh: Evaluation of Trichoderma species against Fusarium oxysporum f. sp. ciceris for integrated management of chickpea wilt. Biological Control, 40, 118-127 (2007).

Dutta, P. and B.C. Das: Management of collar rot of tomato by Trichoderma spp. and chemicals. Indian Phytopath., 55, 235-237 (2002).

Elad, Y., I. Chet and Y. Henis: Parasitism of Trichoderma sp. on Rhizoctonia solani and Sclerotium rolfsii- scanning electron microscopy. Phytopathol., 73, 85-88 (1983).

Garrett, S.D.: Soil Fungi and Soil Fertility. The Macmillan Company, New York, pp. 66-77 (1981).

Gomez K.A. and A.A. Gomez: Statistical Procedures for Agricultural Research, John Wiley \& Sons, Singapore, pp. 139-153 (1984).

Kamil, D., R. Kumar and A. Sinha: Effect of green manuring of Crotalaria juncea L on some soil borne pathogens. Indian Phytopath., 62, 304-309 (2009).

Kapil R. and A.S. Kapoor: Management of white rot of pea incited by Sclerotinia sclerotiorum using Trichoderma spp. and biopesticides. Indian Phytopath., 58,10-16 (2005).

Kapoor, A.S.: Biocontrol potential of Trichoderma spp. against important soilborne diseases of vegetable crops. Indian Phytopath., 61, 492$498(2008)$.

Khilari, K., A.N. Mukhopadhyay and R.S. Yadav: Effect of volatile and non-volatile compounds of $T$. koningii and $G$. virens on growth of $S$. rolfsii, $R$. solani and F. oxisporum f. sp. ciceri. Environ. Ecol., 26, 1961-1964 (2008).

Kumar, R., A. Sinha, S. Srivastava and M. Srivastava: Variation in soil mycobiota associated with decomposition of Sesbania aculeata L. Asian J. Plant Pathol., 5, 37-45 (2011).

Kumar, R., G. Mahajan, S. Srivastava and A. Sinha: Green manuring: A boon for sustainable agriculture and pest management-a review. Agric. Rev., 35, 196-206 (2014).

Larkin, R.P. and T.S. Griffin: Control of soilborne potato diseases using Brassica green manures. Crop Prot., 26, 1067-1077 (2007).

Larkin, R.P.: Green manures and plant disease management. $C A B$ Reviews, 8, 1-10 (2013)

Mandal, U.K., G. Singh, U.S. Victor and K.L. Sharma: Green manuring: its effect on soil properties and crop growth under rice-wheat cropping system. Europ. J. Agronomy, 19, 225-237 (2003).

Manici, L.M., F. Caputo and V. Babini: Effect of green manure on Pythium spp. population and microbial communities in intensive cropping systems. Plant and Soil, 263, 133-142 (2004).

Mathivanan, N., K. Srinivasan and S. Chelliah: Biological control of soilborne diseases of cotton, eggplant, okra and sunflower by Trichoderma viride. Zeits.fur-pflanzenkrank. Pflanzenschutz, 107, 235-244 (2000).

Mayton, H.S., C. Olivier, S.F. Vaughn and R. Loria: Correlation of fungicidal activity of Brassica species with allyl isothiocyanate production in macerated leaf tissue. Phytopathol., 86, 267-271 (1996).

Morton, D.T. and N.H. Stroube: Antagonistic and stimulatory effects of microorganisms upon Sclerotium rolfsii. Phytopathol., 45, 419-420 (1955).

Ochiai, N., M.L. Powelson, R.P. Dick and F.J. Crowe: Effects of green manure type and amendment rate on Verticillium wilt severity and yield of Russet Burbank potato. Plant Disease, 91, 400-406 (2007).

Prabhakaran, N., T. Prameeladevi, M. Sathiyabama and D. Kamil: Screening of different Trichoderma species against agriculturally important foliar plant pathogens. J. Environ. Biol., 36, 191-198 (2015).

Prasad, N.B. and M.R. Kumar: Effect of non-volatile compounds produced by Trichoderma spp. on growth and sclerotial viability of Rhizoctonia solani, incitant of sheath blight of rice. Indian J. Fundamen. Appl. Life Sci., 1, 37-42 (2011).

Pung, H., P.L. Aird and S. Cross: The use of Brassica green manure crops for soil improvement and soil borne disease management. $3^{\text {rd }}$ Australian Soil borne diseases Symposium, pp. 1-2, (2004).

Rekha, D., M.B. Patil, P.S. Shetty, K.M. Swamy and R.B. Gamanagatti: Invitro screening of native Trichoderma isolates against Sclerotium rolfsii causing collar rot of ground nut. Int. J. Sci. Nature, 3, 117-120 (2012).

Srinivasa, N., T. Prameela Devi, S. Sudhirkumar, D. Kamil, J.L. Borah and N. Prabhakaran: Bioefficacy of Trichoderma isolates against soil-borne pathogens. Afr. J. Microbiol. Res., 8, 2710-2723, (2014).

Warcup, J.H.: Method for isolation and estimation of activities of fungi in soil. In: Ecology of Soil Fungi (Eds.: D. Parkinson and J.S. Waids), The University Press, Liverpool, pp. 3-21 (1960). 